\title{
Mycoplasma agalactiae in semen and milk of goat from Pernambuco State, Brazil ${ }^{1}$
}

\author{
Bruno H.L.S. Alves², José G. Silva², André R. Mota², Ana C. Campos³ ${ }^{3}$ José W.P. Júnior ${ }^{4}$, Sandra \\ B. Santos ${ }^{2 *}$ and Rinaldo A. Mota ${ }^{2}$
}

\begin{abstract}
Alves B.H.L.S., Silva J.G., Mota A.R., Campos A.C., Pinheiro Júnior J.W., Santos S.B. \& Mota R.A. 2013. Mycoplasma agalactiae in semen and milk of goat from Pernambuco State, Brazil. Pesquisa Veterinária Brasileira 33(11):1309-1312. Laboratório de Bacterioses dos Animais Domésticos, Departamento de Medicina Veterinária, Universidade Federal Rural de Pernambuco, Av. Dom Manoel de Medeiros s/n, Recife, PE 52171-900, Brazil. E-mail: sanbsantos@gmail.com

In goat and sheep flocks, mycoplasmosis is a disease that may cause severe economical losses associated with polyarthritis, mastitis, agalactia, conjunctivitis, pneumonia and reproductive failure. The latter may involve repeat breeding, granular vulvovaginitis, infertility and abortions. The aim of the present study was to assess the occurrence of Mycoplasma agalactiae $(M a)$ in semen and milk samples from naturally infected goat in the semiarid region from Pernambuco State, Northeast from Brazil. Thirty-nine semen samples and 81 milk samples were submitted to DNA extraction using a commercially available kit and following the manufacturer's instructions. The polymerase chain reaction (PCR) was then performed in accordance with protocols described in the literature. The results of the present study revealed the presence of $M a$ in the DNA of $17.9 \%(7 / 39)$ of the semen samples and $3.7 \%(3 / 81)$ of the milk samples. The results obtained in the present study confirm the elimination of the DNA of $M a$ in the semen and milk samples. The presence of this agent in goat flocks is considered very risky in terms of reproductive disorders and contagious agalactia outbreaks in the Northeast region of Brazil.
\end{abstract}

INDEXS TERMS: Mycoplasma agalactiae, semen, milk, goat, reproductive disorder.

RESUMO.- [Mycoplasma agalactiae em sêmen e leite de caprinos do Estado de Pernambuco.] Em caprinos e ovinos as micoplasmoses causam sérias perdas econômicas associadas com poliartrites, mastites, agalaxia, conjuntivite, pneumonias e falhas reprodutivas. Esta última pode envolver repetição de cio, vulvovaginite granular, infertilidade e abortos. 0 objetivo desse estudo foi verificar a ocorrência de Mycoplasma agalactiae ( $M a$ ) em sêmen e leite de caprinos naturalmente infectados procedentes de regiões semiáridas do Estado de Pernambuco, Nordeste do Brasil.

\footnotetext{
${ }^{1}$ Received on July 19, 2013.

Accepted for publication on September 30, 2013.

${ }^{2}$ Laboratório de Bacterioses dos Animais Domésticos, Departamento de Medicina Veterinária, Universidade Federal Rural de Pernambuco (UFRPE), Av. Dom Manoel de Medeiros s/n, Recife, PE 52171-900, Brazil. *Corresponding author: sanbsantos@gmail.com

${ }^{3}$ Biovetech - Ind. Com. Produtos Biotecnológicos, Recife, PE 50730-260.

${ }^{4}$ Unidade Acadêmica de Garanhuns, UFRPE, Av. Bom Pastor s/n, Boa Vista, Garanhuns, PE 55292-270, Brazil.
}

Foram usadas 39 amostras de sêmen e 81 de leite, as quais foram submetidas à extração do DNA genômico usando um kit comercial, seguindo as instruções do fabricante. A reação da PCR foi realizada de acordo com protocolo previamente descrito na literatura. Os resultados revelaram a presença de DNA de Ma nas amostras de sêmen com uma frequência de $17,9 \%(7 / 39)$ e no leite a frequência encontrada foi de 3,7\% (3/81). Os resultados obtidos no presente estudo confirmam a eliminação de DNA de Ma nas amostras de sêmen e leite analisadas. A presença deste agente nos rebanhos caprinos pode ser considerada um risco para doenças reprodutivas e surtos de agalaxia contagiosa na região Nordeste do Brasil.

TERMOS DE INDEXAÇÃO: Mycoplasma agalactiae, sêmen, leite, caprinos, desordens reprodutivas.

\section{INTRODUCTION}

Mycoplasmas are bacteria from the Mollicutes class and are considered the smallest prokaryotes known without a cell 
wall (Razin et al. 1998). They are often responsible for severe economical losses in livestock production and in small ruminants. These losses are caused by mycoplasmosis syndromes associated with polyarthritis, mastitis, agalactia, conjunctivitis, pneumonia and reproductive failure, which may involve repeat breeding, granular vulvovaginitis, infertility and abortions (DaMassa et al. 1992). Mycoplasma agalactiae $(\mathrm{Ma})$ is the main agent of contagious agalactia (CA). Clinical manifestations occur in the mammary glands, joints and ocular systems and may cause abortions in pregnant goats and sheep (Hasso et al. 1993, Bergonier et al. 1997).

Mycoplasmas cause persistent reproductive failure in the reproductive system of goats and sheep. The species that are most commonly affected are M. bovigenitalium, $M$. agalactiae, Acholeplasma spp. and Ureaplasma spp. (Kapoor et al. 1984, Nicholas et al. 1999, Nicholas 2002, Gil et al. 2003, Gregory et al. 2012, Santos et al. 2013). The presence of these microorganisms in the reproductive system of males has been associated with diseases such as orchitis, seminal vesiculitis, balanoposthitis, epididymitis and other functional disorders related to the morphology and motility of spermatozoa (Panangala et al. 1981, Pilazec \& Truszcynski 1988, Eaglesome et al. 1992, Rizzo et al. 2011). The transmission route is through direct contact during sexual intercourse, artificial insemination or by embryo transfer (Kirkbride 1987, Hasso et al. 1993, Miller et al. 1994). Oliveira (2008) detected a frequency of $72.7 \%$ for Mollicutes in sheep semen in São Paulo, Brazil. In Spain, De la Fe et al. (2009) confirmed the excretion of $M a$ in semen samples from goats. The aim of the present study was to detect the DNA of $M a$ in fresh and frozen semen and milk samples from goats in Brazil.

\section{MATERIALS AND METHODS}

\section{Semen and milk samples}

A total of thirty-nine semen samples were analyzed, being thirteen of fresh semen and twenty-six of frozen semen. The fresh semen samples were collected from goat bucks of different ages and breeding, healthy or had a history of reproductive disorders, and came from farms in the cities of São José do Egito, Floresta, Sertânia and Afogados da Ingazeira, all of which are in a semiarid region of Pernambuco State, in northeastern Brazil. All of the animals were first submitted to a clinical examination. Subsequently, semen samples were collected using the artificial vagina method. The biological material was tested for macroscopic and microscopic characteristics, in accordance with the guidelines of the Brazilian College of Animal Reproduction (CBRA 1998). Furthermore, twenty-six frozen semen samples were obtained from artificial insemination centers (IAC) in the state of Pernambuco. The frozen semen straws were maintained in liquid nitrogen until usage. Eighty-one milk samples were also collected from goats of different breeding and with lactation stages of different properties. The samples were collected after previous teat flushing with water and soap, drying with paper towels and asepsis with alcohol at $70^{\circ} \mathrm{GL}$. A volume of five milliliters of milk was collected in sterile vials $(15 \mathrm{~mL})$ which were labeled with the name or number of the animal. The fresh semen and milk samples were refrigerated at $4{ }^{\circ} \mathrm{C}$ in a cooler with ice and transported to the Laboratory of Infectious Diseases - LDIC-DMV/UFRPE.

\section{PCR for Mycoplasma agalactiae}

The semen and milk samples were processed for DNA extraction using a commercially available kit, according to the manufacturer's instructions (DNA Easy Blood and Tissues Kit ${ }^{\circledR}$, Qiagen Biotechnology, guideline page 25). The PCR assays were performed in a mixture prepared with a volume of $25 \mu \mathrm{L}$, containing $5 \mu \mathrm{L}$ of DNA template, $30 \mathrm{pmol}$ of each primer, $\mathrm{MgCl}_{2}(1.5 \mathrm{mM})$, buffer $[10 \mathrm{mM}$ of Tris- $\mathrm{HCl}, \mathrm{pH} 8.3)$, a mix of deoxynucleoside triphosphate $(50 \mu \mathrm{M})$, Taq DNA Polymerase (2.5U) and Milli-Q ultrapure water. In-vitro amplifications were performed in the thermo cycler model PTC100 (MJ-Research ${ }^{\circledR}$ ) with primers (MarFor and MarRev) and a thermal profile, based on the protocol described by González et al. (1995), based in variable region V6 of the 16SrRNA gene. The standard, Mycoplasma agalactiae $(0.8 \mathrm{ng} / \mu \mathrm{L}$ ) (Strain BrPB01, Paraiba, Brasil, Gen Bank No JQ612164), was used as a positive control for PCR reactions. Ultrapure water was used as a negative control. The PCR products were analyzed by agarose gel at 1.5\% electrophoresis and visualized by staining with Bluegreen $₫$ and viewing under ultraviolet light. All analysis was photodocumented.

\section{RESULTS AND DISCUSSION}

Prior to semen collection, the goat bucks were clinically examined. None of the animals exhibited clinical symptoms associated with CA infection or lesions in the external genitalia. No abnormalities were found in the analysis of the quality, activity and motility of the semen. Gregory et al. (2012) reported the presence of Mycoplasma and Ureaplas$m a$ in the semen of sheep after recording no abnormalities in the preliminary clinical examination. Based on the PCR, all fresh semen samples $(0 / 13)$ were negative for $M a$. In goats of the northeast region more investigations are needed for determine the importance of the semen in the transmission of $M a$ during sexual intercourse. In the present study few goat bucks were available and the frequency of Ma may have been underestimated. Therefore, further studies are needed with a larger number of animals to establish the excretion dynamics in the fresh semen of goats. In the microbiological analysis of the fresh semen was possible identify others bacterial agents (unpublished data).

In frozen semen, the frequency of $M a$ was $26.9 \%(7 / 26)$. This is the first time that $M a$ in frozen semen of goats has been found in artificial insemination centers in Pernambuco state. $M a$ in others occasions has been reported in outbreaks of CA in other semiarid regions in Brazil which are currently considered endemic for $M a$ and CA (Azevedo et al. 2006). Unfortunately, there are no studies of the influence of this microorganism in reproductive diseases.

In Brazil, the significance of mycoplasmosis as a cause of reproductive failure in goats and sheep is unknown. However, functional alterations in the semen of sheep bucks have been reported along with the presence of Mycoplasma spp. and Ureaplasma spp. (Gregory et al. 2012). Santos et al. (2013) detected a frequency of $26.0 \%$ for Mollicutes and $12.0 \%$ for Ureaplasma spp. in the semen of sheep from the Northeast region of Brazil. The role of these asymptomatic goat bucks in the spread of CA in the northeast of Brazil is as yet unknown. However, the transmission of $M a$ through semen has been confirmed in Spain by De la Fe et al. (2009) and in Iraq by Hasso et al. (1993). 
The high frequency detected in frozen goat semen may be a risk factor for outbreaks of CA and reproductive disorders in regions of intensive goat and sheep breeding in Brazil. The isolation of Mollicutes in treated frozen semen has been reported in bovine (Cardoso 2003, Marques et al. 2011). According Marques et al. (2011) addition of antibiotics to semen before freezing reduce the number of microrganisms, but no eliminate ureaplasmas. Cardoso \& Vasconcellos (2004) report that antibiotics currently added to semen diluents are ineffective against Mollicutes. These results in frozen semen of goats arouses for veterinarians that frozen semen may be a potential infection route during artificial insemination. Artificial insemination centers must be monitored in a program of mycoplasmosis control in Brazil.

In milk samples, the frequency of $M a$ DNA, obtained from positive animals, was 3.7\% (3/81). The milk frequency detected in the PCR was lower than that found by Azevedo et al. (2006) and by Campos et al. (2009). These authors reported a prevalence of $100.0 \%$ and $83.2 \%$, respectively, in small ruminants after an outbreak of CA in Paraiba, Brazil. However, these authors conducted their experiments in properties that had CA outbreaks and a higher frequency of positive animals was expected. Al-Momani et al. (2006) reported a positive $M a$ frequency of $36 \%$ among animals in Jordan, whereas De La Fe et al. (2005) reported a frequency of $40 \%$ in Spain. In the present study, the low frequency of $M a$ in the milk of the goats may indicate different stages mycoplasmosis in the flocks studied, as a chronic process or subclinical only harbor a small number are eliminated in the milk. Moreover, the continuous attempts at treating mastitis and CA with current antibiotics administered for a long period in flocks of the region may have influenced the elimination of agent in the milk in the period of the sampling. In this study was verified clinical and subclinical mastitis in the goat flocks.

\section{CONCLUSION}

The results confirmed the elimination of Ma DNA in semen samples from goat bucks and in the milk of goats. The present study is the first report of this agent in frozen semen in the Northeast region of Brazil.

Research Ethics Committee.- The present study was approved by the ethics committee of UFRPE/DMV under Proc. 006/2011.

Acknowledgements.- This study was supported by Fundação de Amparo à Ciência e Tecnologia do Estado de Pernambuco (FACEPE) (Proc. APQ 1512-20 5.05/10 and APQ-1226-5.05/10).

\section{REFERENCES}

Al-Momani W., Halablab M.A., Abo-Shehada M.N., Miles K., McAuliffe L. \& Nicholas R.A.J. 2006. Isolation and molecular identification of small ruminant mycoplasmas in Jordan. Small Rumin. Res. 65:106-112.

Azevedo E.O., Alcântara M.D.B., Nascimento E.R., Tabosa I.V., Barreto M.L., Almeida J.F., Araújo M.D'O., Rodrigues A.R.O., Riet-Correa F. \& Castro R.S. 2006. Contagious agalactia by Mycoplasma agalactiae in small ruminants in Brazil: first report. Braz. J. Microbiol. 37: 576-581.

Bergonier D., Berthelot X. \& Poumarat P. 1997. Contagious agalactia of small ruminants: current knowledge concerning epidemiology, diagnosis and control. Rev. Sci. Technol. 16:848-873.
CBRA 1998. Manual for Examination and Avaliation of Animal Semen. $2^{\text {nd }}$ ed. Colégio Brasileiro de Reprodução Animal, Belo Horizonte. 49p.

Campos A.C., Teles J.A.A., Azevedo E.O., Nascimento E.R., Oliveira M.M.M., Nascimento S.A. \& Castro R.S. 2009. ELISA protein G for the diagnosis of contagious agalactia in small ruminants. Small Rumin. Res. 84:70-75.

Cardoso M.V. 2003. Mycoplasma bovis, M. bovigenitalium e Ureaplasma diversum em touros. Diagnóstico, impacto na reprodução e ensaio terapêutico. Tese de Doutorado em Reprodução Animal, Faculdade de Medicina Veterinária e Zootecnia, Universidade de São Paulo, São Paulo, SP. 89p.

Cardoso M.V. \& Vasconcelos S.A. 2004. Importância das micoplasmoses na infertilidade de touros. Arqs Inst. Biol., São Paulo 71(2):257-265.

DaMassa A.J., Wakenell P.S. \& Brooks D.L. 1992. Mycoplasmas of goats and sheep: review article. J. Vet. Diagn. Invest. 4:101-113.

De la Fe C., Assunção P., Antunes T., Rosales R.S. \& Poveda J.B. 2005. Microbiological survey for Mycoplasma spp. in a contagious agalactia endemic area. Vet. J. 170:257-259.

De la Fe C., Amores J., Martin A.G., Sanchez A., Contreras A. \& Corrales J.C. 2009. Mycoplasma agalactiae detected in the semen of goat bucks. Theriogenology 72:1278-1281.

Eaglesome M.D., Garcia M.M. \& Stewart R.B. 1992. Microbial agents associated with bovine genital tract infections and semen. Part II. Haemophilus sonnus, Mycoplasma spp., Ureaplasma spp. and Chlamydia, pathogens and semen contaminants: treatment of bull semen with antimicrobial agents. Vet. Bull. 62:887-910.

Gil M.C., Peña F.J., Mendoza H.J. \& Gomez L. 2003. Genital lesions in an outbreak of caprine contagious agalactia caused by Mycoplasma agalactiae and Mycoplasma putrefaciens. J. Vet. Med. B 50:484-487.

González Y.R.C., Bascuñana C.R., Bolske G., Mattsson J.G., Molina C.F. \& Johansson K.E. 1995. In vitro amplification of the 16s rRNA genes from Mycoplasma bovis and Mycoplasma agalactiae by PCR. Vet. Microbiol. 47:183-190.

Gregory L., Rizzo H., Gaeta N.C., Tortorelli G., Cardoso M.V., Mettifogo E., Buzinhani M. \& Timenetsky J. 2012. Interference of Mycoplasma spp. or Ureaplasma spp. in Ovine Semen Quality. J. Microbiol. Res. 2:118-122.

Hasso S.A., AI-Aubaidi J.M. \& Al-Darraji A.M. 1993. Contagious agalactia in goats: It's severity as related to the route of infection and pregnancy. Small Rumin. Res. 10:263-275.

Kapoor S.G., Singh P.P. \& Pathak R.C. 1984. Prevalence of mycoplasma/ acholeplasma in the genital tract of sheep. Indian J. Animal Sci. 54:553556.

Kirkbride C.A. 1987. Mycoplasma, Ureaplasma, and Acholeplasma infections of bovine genitalia. Vet. Clin. North. Am., Food Anim. 3:575-591.

Marques L.M., Buzinhani M., Neto R.L., Oliveira R.C., Yamaguti M., Guimarães A.M. \& Timenetsky J. 2011. Detection of Ureaplasma diversum in bovine semen straws for artificial insemination. Vet. Rec. 165(7):572-573.

Miller R.B., Chelmonska-Soyta A., Smits B., Foster R. \& Rosendal S. 1994. Ureaplasma diversum as a cause of reproductive disease in cattle. Vet. Clin. North Am., Food Anim. 10:479-490.

Nicholas R.A.J., Wessels M., Orme P.K., Wood E. \& Sachse K. 1999. Isolation of Mycoplasma ovine/caprine serogroup 11 from infertile sheep in Britain. Vet. Rec. 9:434.

Nicholas R.A.J. 2002. Improvements in the diagnosis and control of diseases of small ruminants caused by mycoplasmas. Small Rumin. Res. 45:145-49.

Oliveira C.R. 2008. Isolamento de ureaplasma e micoplasma do trato reprodutivo de ovinos e caprinos e tipificação genotípica por meio da PFGE e sequenciamento do gene 16S rRNA. Tese de Doutorado em Epidemiologia Experimental e Aplicada às Zoonoses, Faculdade de Medicina Veterinária e Zootecnia, Universidade de São Paulo, São Paulo, SP. 138p.

Panangala V.S., Winter A.J., Wijesinha A. \& Foote R.H. 1981. Decreased motility of Bull spermatozoa caused by Mycoplasma bovigenitalium. Am. J. Vet. Res. 42:2090-2093.

Pilazec J. \& Truszcynski M. 1988. Affinity of microorganisms of the genus 
Ureaplasma to the reproductive organs of cattle. Comp. Immunol. Microb. 11:177-180.

Razin S., Yogev D. \& Naot Y. 1998. Molecular biology and pathogenicity of mycoplasmas. Microbiol. Mol. Biol. Rev. 62:1094-1156.

Rizzo H., Junior E.B.S.M., Oliveira R.C., Yamaguti M., Buzinhani M., Timenetsky J. \& Gregory L. 2011. Mollicutes isolation and PCR on ovine vaginal mucous and its association with reproductive problems in Piedade, SP, Brazil. Ciência Rural 41:324-329.

Santos S.B., Neto O.L.S., Albuquerque P.P.F., Mota A.R., Kim P.C.P., Moraes E.P.B.X., Nascimento E.R. \& Mota R.A. 2013. Detection of Mycoplasma spp. and Ureaplasma spp. in semen samples from sheep in Brazil. Braz. J. Microbiol. 44:3. 